\title{
Prognostication of serial post-intensity-modulated radiation therapy undetectable plasma EBV DNA for nasopharyngeal carcinoma
}

\author{
Victor Ho-Fun Lee ${ }^{1}$, Dora Lai-Wan Kwong ${ }^{1}$, To-Wai Leung ${ }^{1}$, Cheuk-Wai Choi ${ }^{1}$, \\ Vincent Lai ${ }^{2}$, Lydia Ng ${ }^{3}$, Ka-On Lam ${ }^{1}$, Sherry Chor-Yi Ng ${ }^{1}$, Chun-Kin Sze ${ }^{1}$, Chi-Chung \\ Tong ${ }^{1}$, Patty Pui-Ying Ho ${ }^{1}$, Wing-Lok Chan ${ }^{1}$, Lai-San Wong ${ }^{1}$, Dennis Kwok-Chuen \\ Leung $^{1}$, Sum-Yin Chan ${ }^{1}$, Pek-Lan Khong ${ }^{2}$ \\ ${ }^{1}$ Department of Clinical Oncology, Queen Mary Hospital, Li Ka Shing Faculty of Medicine, The University of Hong Kong, \\ Hong Kong \\ ${ }^{2}$ Department of Diagnostic Radiology, Li Ka Shing Faculty of Medicine, The University of Hong Kong, Hong Kong \\ ${ }^{3}$ Department of Radiation Oncology, University of Southern California, Los Angeles, California, USA \\ Correspondence to: Victor Ho-Fun Lee, email: vhflee@hku.hk \\ Keywords: intensity-modulated radiation therapy, nasopharyngeal carcinoma, non-metastatic, plasma EBV DNA, prognostic factors \\ Received: June 30, 2016 \\ Accepted: November 22, 2016 \\ Published: December 24, 2016
}

\section{ABSTRACT}

Plasma Epstein-Barr virus (EBV) DNA titers have been used to monitor treatment response and provide prognostic information on survival for nasopharyngeal carcinoma (NPC). However, the long-term prognostic role of pretreatment and posttreatment titers after radical contemporaneous radiation therapy remains uncertain. We recruited 260 evaluable patients with non-metastatic NPC treated with radical intensity-modulated radiation therapy (IMRT) with or without adjunct chemotherapy. Plasma EBV DNA titers at baseline and then 8 weeks and 6 months after IMRT were measured. Cox regression models were employed to identify interaction between post-IMRT $8^{\text {th }}$ week and $6^{\text {th }}$ month undetectable titers and 3-year survival endpoints. Concordance indices $(\mathrm{Ct})$ from time-dependent receiver-operating characteristics (TDROC) were compared between patients with post-IMRT undetectable and those with detectable titers. After a median follow-up duration of 3.4 years (range 1.4-4.6 years), patients with post-IMRT $8^{\text {th }}$ week and $6^{\text {th }}$ month undetectable plasma EBV DNA titers enjoyed longer 3-year survival endpoints than those who had detectable titers at the same time points. Post-IMRT $8^{\text {th }}$ week, and more significantly, post-IMRT $6^{\text {th }}$ month undetectable plasma EBV DNA were the only significant prognostic factors of 3-year survival endpoints. Ct values for all 3-year survival endpoints for both post-IMRT $8^{\text {th }}$ week and $6^{\text {th }}$ month undetectable plasma EBV DNA were significantly higher in those with stage IVA-IVB diseases compared to stage I-III counterparts. Early post-IMRT undetectable plasma EBV DNA titers were prognostic of 3-year survival endpoints in patients with non-metastatic NPC. Intensified treatment should be further explored for patients with persistently detectable titers after IMRT.

\section{INTRODUCTION}

Nasopharyngeal carcinoma (NPC) is unique in its geographical distribution with prevalence in Southern China, Hong Kong, Taiwan, Singapore and Malaysia as well as association with Epstein-Barr virus (EBV) [1, 2]. According to global cancer registry, NPC ranked $11^{\text {th }}$ most common among all malignancies in China in 2008 with an incidence of 2.8/100000 person-years in men and $1.9 / 100000$ person-years in females. The most common histological types are undifferentiated non-keratinizing carcinoma (WHO Type III) and differentiated nonkeratinizing carcinoma (WHO Type II). Radiation therapy alone is offered for stage I and II disease while concurrent chemoradiation is indicated for locally advanced stage III to IVB disease [3]. Intensity-modulated radiation therapy 
(IMRT) has been the most contemporaneous radiation therapy technique for the past decade due to its superior tumor coverage and dose sparing of critical normal structures from unnecessary radiation, leading to better treatment outcomes and toxicity profiles [4-11]. Plasma EBV DNA titer has been found important in both diagnosis and monitoring of treatment response during and after definitive treatment [12-22]. However, its role in the IMRT era remains uncertain, and the appropriate time points for its surveillance after IMRT are undefined. Currently plasma EBV DNA titer has yet to be recommended by the American Joint Committee on Cancer (AJCC) staging manual and European Society for Medical Oncology (ESMO) as a tumor marker in routine clinical staging and posttreatment monitoring [23]. There is an unmet and urgent need for identifying its role at baseline and in posttreatment monitoring to improve risk stratification, leading to closer surveillance and intensified treatment in poor-risk groups in the modern era of radiation therapy. We initiated this prospective observational study on measuring baseline and serial plasma EBV DNA titers for all patients with newly diagnosed non-metastatic NPC to determine the prognostic value of early post-IMRT plasma EBV DNA on long-term survival outcomes. We now presented our preliminary results on 3-year survival endpoints. This study was registered with the National Cancer Trial Registry as NCT02476669 (ClinicalTrials.gov).

\section{RESULTS}

The study schematic diagram was shown (Figure 1). A total of 289 consecutive patients were recruited from July 2010 to June 2013. Of them, 29 patients were excluded from subsequent analyses after written informed consent: 23 patients did not have blood taken for baseline or serial plasma EBV DNA, three patients suffered from stage IVC metastatic disease confirmed by PETCT scan and another three patients died during IMRT (two died from sepsis and one committed suicide). The characteristics of the remaining 260 patients for analysis were displayed in Table 1.

\section{Treatment outcomes after IMRT and their plasma EBV DNA at different time points}

The median baseline plasma EBV DNA titers for all patients was 934 copies/ml (range 10-1575000 copies/ $\mathrm{ml}$ ). Mood's median test showed that the medians were significantly different across different overall stages $(P=0.003)$ (Figure 2). All patients completed IMRT without treatment interruption. Forty-six patients received IMRT alone for their early-stage disease (40 patients) or because of their advanced age and/or significant medical contraindications to chemotherapy (6 patients). However, these 6 patients were still free from relapse. At 8 weeks after IMRT, 30 patients still had elevated plasma EBV DNA (range 14-4512 copies/ml); all but 1 had undetectable titers at 12 weeks after IMRT and this remaining patient's plasma EBV DNA was then undetectable at 16 weeks after IMRT. Another patient, despite undetectable plasma EBV DNA, had confirmed local persistence at 12 weeks. He received additional stereotactic IMRT boost (20Gy in 8 fractions over 1.5 weeks) without any residual disease noted afterwards. His plasma EBV DNA was persistently undetectable before and after stereotactic boost. Five patients developed progressive disease with distant metastases between 8 weeks and 6 months after IMRT, and thus they were only included in the subsequent TDROC and survival analysis using post-IMRT $8^{\text {th }}$ week (but not $6^{\text {th }}$ month) undetectable plasma EBV DNA as stratifying factor. Seventeen patients had elevated plasma EBV DNA (range 19-29375 copies/ $\mathrm{ml}$ ) at 6 months after IMRT. Of them, 3 developed local recurrence, 1 patient suffered from regional nodal failure, 5 patients had distant metastases, 1 patient had both regional and distant failure, 1 patient had local and distant failure and the remaining 6 were still free of relapse. After a median follow-up duration of 3.4 years (range 1.4-4.6 years), 10, 5 and 19 patients had local failure, regional failures and distant metastases, translated into $96.2 \%$, $98.1 \%$ and $92.7 \%$ for the 3-year local, regional and distant metastasis control rates respectively. The 3-year LFFS, RFFS, DMFS, PFS, CSS and OS were 95.2\%, 96.9\%, $91.2 \%, 88.0 \%, 95.8 \%, 93.9 \%$ respectively. The KaplanMeier estimates of all survival endpoints for all stages were also shown (Supplementary Figure S1).

\section{Correlation of post-IMRT $8^{\text {th }}$ week and $6^{\text {th }}$ month undetectable plasma EBV DNA with long-term survival endpoints}

Patients who had post-IMRT $8^{\text {th }}$ week and $6^{\text {th }}$ month undetectable plasma EBV DNA enjoyed longer 3-year survival endpoints compared to those who had post-IMRT detectable titers at the corresponding time points, except LFFS stratified by post-IMRT $8^{\text {th }}$ week undetectable plasma EBV DNA (Table 2, Figure 3 and Figure 4). In particular, greater survival differences were revealed between patients with undetectable and detectable postIMRT $6^{\text {th }}$ month plasma EBV DNA. The prognostic significances between post-IMRT $8^{\text {th }}$ week and $6^{\text {th }}$ month undetectable plasma EBV DNA and the survival endpoints were further evaluated in univariable and multivariable Cox models (Supplementary Table S1 to Table S3). Only post-IMRT $8^{\text {th }}$ week and $6^{\text {th }}$ month undetectable plasma EBV DNA were prognostic of all survival endpoints (except for LFFS stratified by post-IMRT $8^{\text {th }}$ week undetectable plasma EBV DNA), while baseline plasma EBV DNA was prognostic of LFFS, RFFS, DMFS and PFS only (Supplementary Table S1 to Table S3).

TDROC analysis revealed significantly higher $\mathrm{Ct}$ indices and AUC values in stage IVA to IVB diseases 


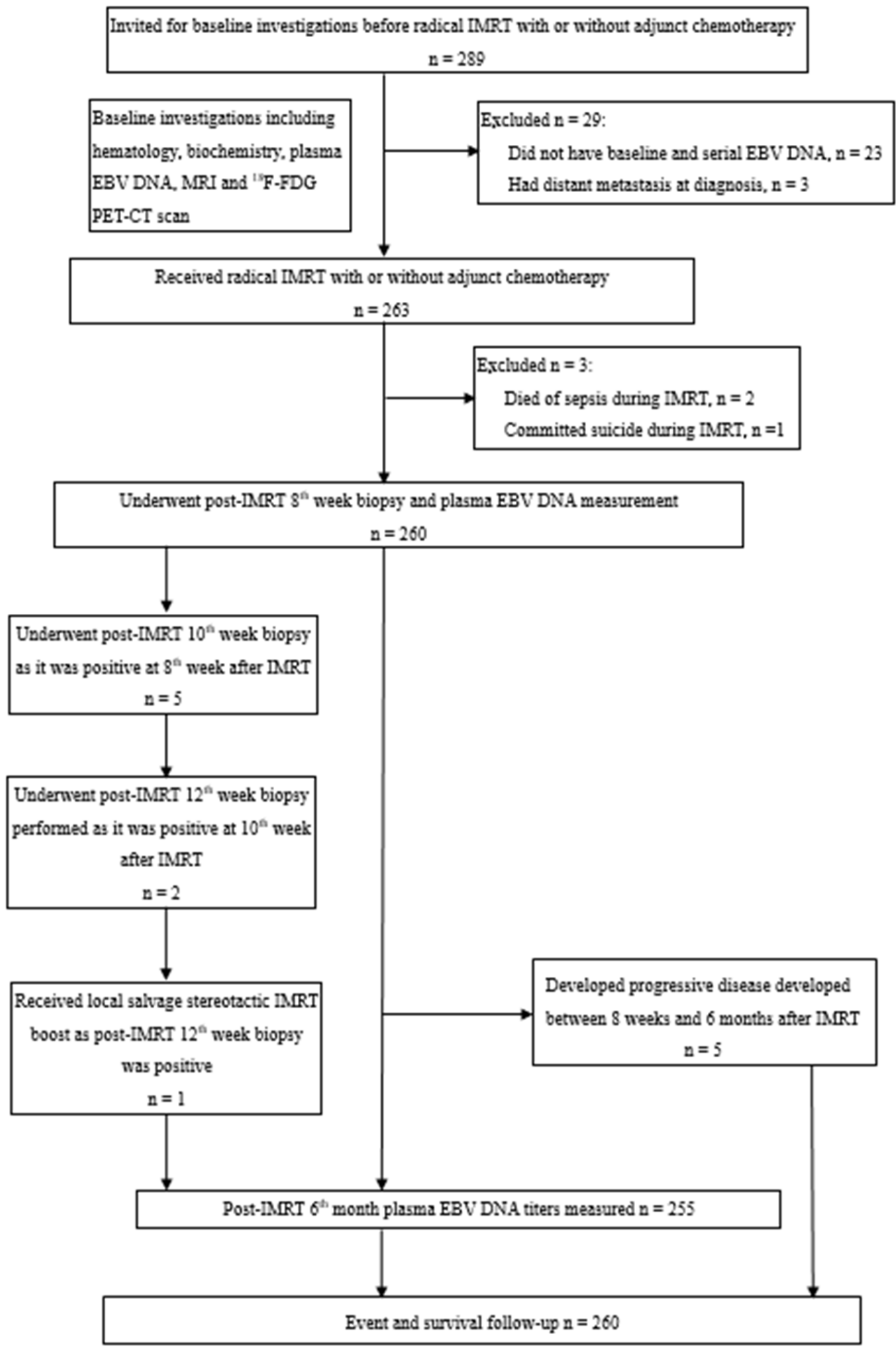

Figure 1: Participant flow in the current study. DNA: deoxyribonucleic acid, EBV: Epstein-Barr virus, 18F-FDG: [18F] fluorodeoxyglucose, IMRT: intensity-modulated radiation therapy, MRI: magnetic resonance imaging, NPC: nasopharyngeal carcinoma, PET-CT: positron-emission tomography with integrated contrast-enhanced computed tomography. 
Table 1: Characteristics of study patients

\begin{tabular}{|c|c|}
\hline \multirow{2}{*}{ Characteristic } & $n=260$ \\
\hline & No. of patients $(\%)$ \\
\hline Mean age in years (range) & $53(16-91)$ \\
\hline Male/female & $183(70.4) / 77(29.6)$ \\
\hline \multicolumn{2}{|l|}{ ECOG performance status } \\
\hline 0 & $16(6.2)$ \\
\hline 1 & $244(93.8)$ \\
\hline \multicolumn{2}{|l|}{ T-classification } \\
\hline $\mathrm{T} 1$ & $77(29.6)$ \\
\hline $\mathrm{T} 2$ & $28(10.8)$ \\
\hline $\mathrm{T} 3$ & $115(44.2)$ \\
\hline $\mathrm{T} 4$ & $40(15.4)$ \\
\hline \multicolumn{2}{|l|}{ N-classification } \\
\hline N0 & $30(11.5)$ \\
\hline N1 & $74(28.5)$ \\
\hline $\mathrm{N} 2$ & $121(46.5)$ \\
\hline N3a & $4(1.5)$ \\
\hline $\mathrm{N} 3 \mathrm{~b}$ & $31(11.9)$ \\
\hline \multicolumn{2}{|l|}{ Overall stage } \\
\hline $\mathrm{I}$ & $17(6.5)$ \\
\hline II & $38(14.6)$ \\
\hline III & $135(51.9)$ \\
\hline IVA & $35(13.5)$ \\
\hline IVB & $35(13.5)$ \\
\hline \multicolumn{2}{|l|}{ Laterality of primary tumor } \\
\hline Midline & $142(54.6)$ \\
\hline Left & $57(21.9)$ \\
\hline Right & $61(23.5)$ \\
\hline Retropharyngeal node present & $200(76.9)$ \\
\hline \multicolumn{2}{|l|}{ Laterality of retropharyngeal node $(n=200)$} \\
\hline Ipsilateral & $88(44.0)$ \\
\hline Contralateral & $3(1.5)$ \\
\hline Bilateral & $109(54.5)$ \\
\hline Median baseline plasma EBV DNA in copies/ml (range) & $934(10-1575000)$ \\
\hline Stage I $(n=17)$ & $13(10-210)$ \\
\hline Stage II $(\mathrm{n}=38)$ & $746(10-21250)$ \\
\hline Stage III $(\mathrm{n}=135)$ & $847(11-175000)$ \\
\hline Stage IVA $(n=35)$ & $1400(10-90500)$ \\
\hline Stage IVB $(\mathrm{n}=35)$ & $7625(12-1575000)$ \\
\hline Radical IMRT only & $46(17.7)$ \\
\hline Concurrent chemoradiation & $26(10.0)$ \\
\hline Induction chemotherapy then concurrent chemoradiation & $89(34.2)$ \\
\hline Concurrent chemoradiation then adjuvant chemotherapy & $99(38.1)$ \\
\hline
\end{tabular}

DNA: deoxyribonucleic acid, EBV: Epstein-Barr virus, ECOG: Eastern Cooperative Oncology Group, IMRT: intensitymodulated radiation therapy. 
compared to stage I to III counterparts for all survival endpoints using both post-IMRT $8^{\text {th }}$ week and $6^{\text {th }}$ month undetectable plasma EBV DNA as stratification (Supplementary Table S4 and Supplementary Figure $\mathrm{S} 2)$. In addition, the $\mathrm{Ct}$ indices and AUC values were consistently higher for post-IMRT $6^{\text {th }}$ month undetectable plasma EBV DNA compared to post-IMRT $8^{\text {th }}$ week undetectable plasma EBV DNA. These indicated that postIMRT undetectable plasma EBV DNA possessed a higher predictive power of survival endpoints for more advanced stage disease than earlier stage disease and the power was stronger with post-IMRT $6^{\text {th }}$ month undetectable plasma EBV DNA than with post-IMRT $8^{\text {th }}$ week undetectable titers. This was also illustrated in ordinary ROC analyses with, in general, higher AUC values for post-IMRT $6^{\text {th }}$ month undetectable plasma EBV DNA in each survival endpoint (Supplementary Figure S3).

\section{DISCUSSION}

The discovery of plasma EBV DNA has established itself as an accurate biomarker for detection, surveillance and prognostication of NPC. For the past 15 years, numerous studies have investigated the correlation between pretreatment plasma EBV DNA levels and clinical stage, tumor load and treatment outcomes [12-21]. However, either these studies were performed when the $5^{\text {th }}$ and $6^{\text {th }}$ edition of AJCC staging system were in use, when modern radiation therapy techniques for example IMRT was not fully implemented or when various cut-off values of pretreatment and posttreatment plasma EBV DNA titers were used in the exploratory analyses. In addition, PETCT scan as complete and accurate staging workup was not employed in previous studies; thus, some patients might have been understaged. Though Peng et al in their recent

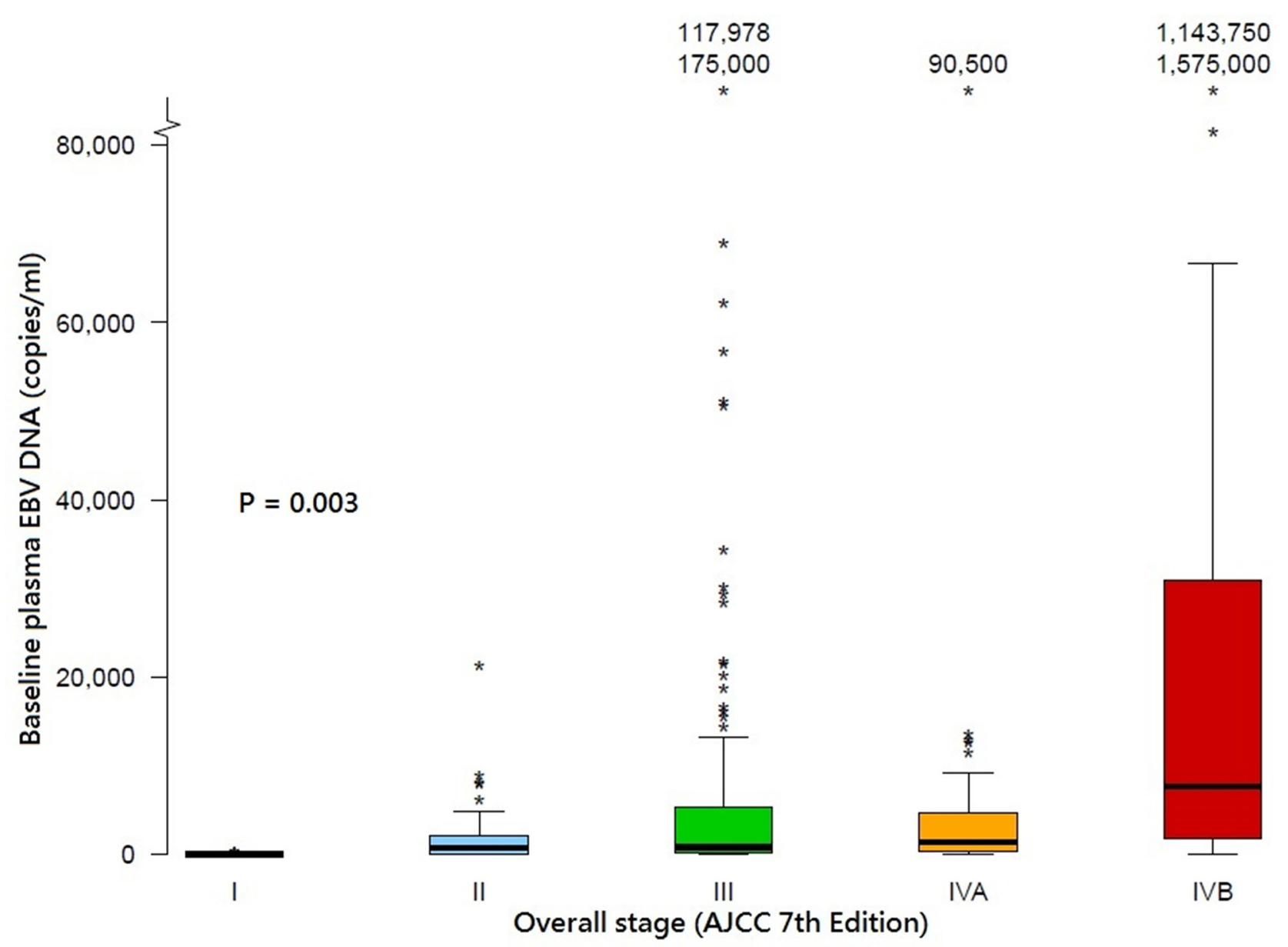

Figure 2: Box and whisker plot showing the distribution of baseline plasma EBV DNA titers across different overall stages of NPC in the study population. The band inside the boxes indicates the median. The boxes indicate the interquartile range and the whiskers indicate the values between ( 1 st quartile - step) and ( 3 rd quartile + step) where step $=1.5 \times$ interquartile range. The * indicates an extreme outlier with its value either 2 steps below the 1st quartile or 2 steps above the 3rd quartile. AJCC: American Joint Committee on Cancer; DNA, deoxyribonucleic acid, EBV: Epstein-Barr virus. 
Table 2: Impact of undetectable plasma EBV DNA at 8 weeks and 6 months after IMRT on various survival endpoints

\begin{tabular}{|c|c|c|c|c|c|c|}
\hline & \multicolumn{3}{|c|}{ Post-IMRT 8th week plasma EBV DNA } & \multicolumn{3}{|c|}{ Plasma IMRT $6^{\text {th }}$ month plasma EBV DNA } \\
\hline & 0 copies $/ \mathrm{ml}$ & $>0$ copies $/ \mathrm{ml}$ & $\boldsymbol{P}$ & 0 copies $/ \mathbf{m l}$ & $>0$ copies $/ \mathrm{ml}$ & $\boldsymbol{P}$ \\
\hline LFFS & & & 0.394 & & & $<0.001$ \\
\hline Median (months) & NR & NR & & NR & NR & \\
\hline Mean (months) & 49.0 & 47.3 & & 49.4 & 39.8 & \\
\hline $95 \% \mathrm{CI}$ & $48.1-49.9$ & $44.2-50.5$ & & $48.6-50.2$ & $32.8-46.8$ & \\
\hline HR & \multicolumn{2}{|c|}{0.52} & & \multicolumn{2}{|c|}{0.10} & \\
\hline $95 \% \mathrm{CI}$ & \multicolumn{2}{|c|}{0.11 to 2.43} & & \multicolumn{2}{|c|}{$0.03-0.37$} & \\
\hline RFFS & & & 0.034 & & & 0.004 \\
\hline Median (months) & NR & NR & & NR & NR & \\
\hline Mean (months) & 49.9 & 47.0 & & 49.9 & 44.3 & \\
\hline $95 \% \mathrm{CI}$ & $49.3-50.4$ & $43.4-50.6$ & & $49.3-50.4$ & $38.9-49.7$ & \\
\hline $\mathrm{HR}$ & \multicolumn{2}{|c|}{0.18} & & \multicolumn{2}{|c|}{0.11} & \\
\hline $95 \% \mathrm{CI}$ & \multicolumn{2}{|c|}{$0.03-0.98$} & & \multicolumn{2}{|c|}{$0.02-0.67$} & \\
\hline DMFS & & & $<0.001$ & & & $<0.001$ \\
\hline Median (months) & NR & NR & & NR & NR & \\
\hline Mean (months) & 48.5 & 39.0 & & 48.7 & 32.6 & \\
\hline $95 \% \mathrm{CI}$ & $47.4-49.6$ & $32.7-45.3$ & & $47.7-49.7$ & $23.9-41.2$ & \\
\hline HR & \multicolumn{2}{|c|}{0.14} & & \multicolumn{2}{|c|}{0.08} & \\
\hline $95 \% \mathrm{CI}$ & \multicolumn{2}{|c|}{$0.06-0.36$} & & \multicolumn{2}{|c|}{$0.03-0.20$} & \\
\hline PFS & & & $<0.001$ & & & $<0.001$ \\
\hline Median (months) & NR & NR & & NR & NR & \\
\hline Mean (months) & 47.8 & 36.7 & & 48.4 & 25.4 & \\
\hline $95 \% \mathrm{CI}$ & $46.6-49.1$ & $30.2-43.2$ & & $47.4-49.5$ & $17.4-33.4$ & \\
\hline HR & \multicolumn{2}{|c|}{0.16} & & \multicolumn{2}{|c|}{0.05} & \\
\hline $95 \% \mathrm{CI}$ & \multicolumn{2}{|c|}{$0.07-0.35$} & & \multicolumn{2}{|c|}{$0.02-0.11$} & \\
\hline CSS & & & 0.002 & & & $<0.001$ \\
\hline Median (months) & NR & NR & & NR & NR & \\
\hline Mean (months) & 49.5 & 44.8 & & 49.7 & 43.8 & \\
\hline $95 \% \mathrm{CI}$ & $48.8-50.3$ & $40.4-49.2$ & & $49.1-50.3$ & $39.3-48.4$ & \\
\hline HR & \multicolumn{2}{|c|}{0.16} & \multicolumn{4}{|c|}{0.11} \\
\hline $95 \% \mathrm{CI}$ & \multicolumn{2}{|c|}{$0.04-0.60$} & & \multicolumn{2}{|c|}{$0.03-0.49$} & \\
\hline OS & & & 0.028 & & & 0.004 \\
\hline Median (months) & NR & NR & & NR & NR & \\
\hline Mean (months) & 48.8 & 44.8 & & 49.4 & 43.8 & \\
\hline $95 \% \mathrm{CI}$ & $47.8-49.8$ & $40.4-49.2$ & & $48.6-50.2$ & $39.3-48.4$ & \\
\hline HR & \multicolumn{2}{|c|}{0.29} & \multicolumn{4}{|c|}{0.17} \\
\hline $95 \% \mathrm{CI}$ & \multicolumn{2}{|c|}{$0.09-0.94$} & & \multicolumn{2}{|c|}{$0.04-0.67$} & \\
\hline
\end{tabular}

CI: confidence interval, CSS: cancer-specific survival, DMFS: distant metastasis-free survival, HR: hazard ratio, IMRT: intensity-modulated radiation therapy, LFFS: local failure-free survival, NR: not reached, OS: overall survival, PFS: progression-free survival, RFFS: regional failure-free survival. 
A
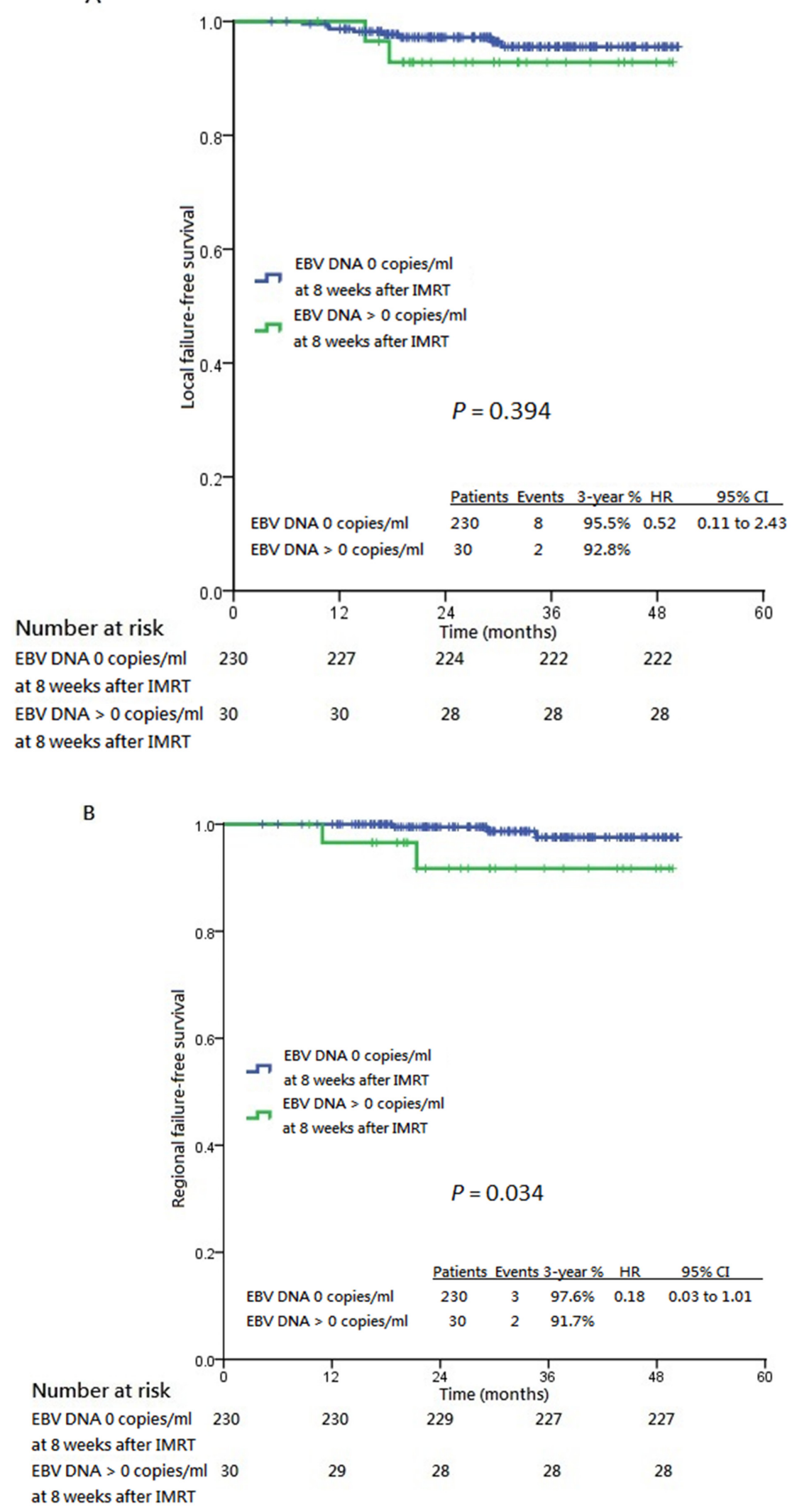

Figure 3: Kaplan-Meier estimates of all survival endpoints stratified by post-IMRT 8th week undetectable plasma EBV DNA. Panel A. shows local failure-free survival. Panel B. shows regional failure-free survival.

(Continued) 
C

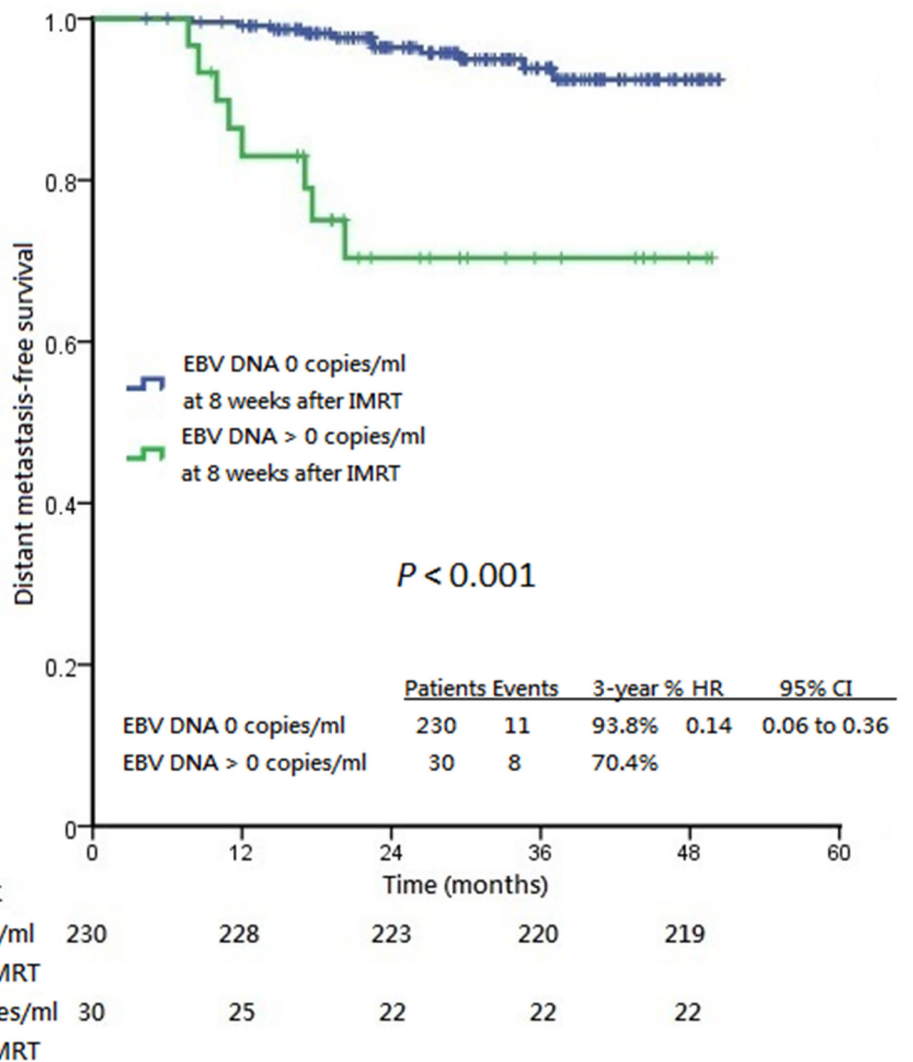

D

Number at risk

EBV DNA 0 copies $/ \mathrm{ml} \quad 230$

at 8 weeks after IMRT

EBV DNA > 0 copies $/ \mathrm{ml} 30$

at 8 weeks after IMRT

$\begin{array}{llll}228 & 223 & 220 & 219 \\ 25 & 22 & 22 & 22\end{array}$

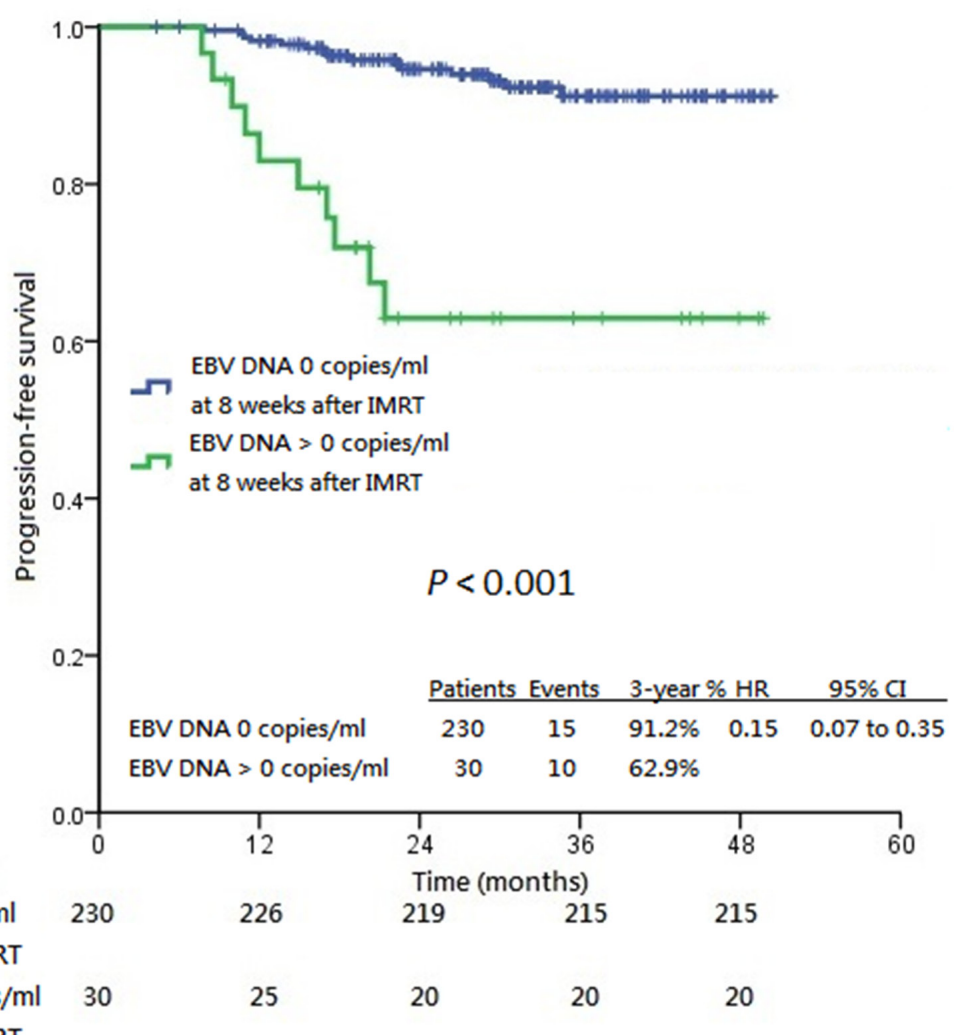

Figure 3 (Continued): Panel C. shows distant metastasis-free survival. Panel D. shows progression-free survival.

(Continued) 


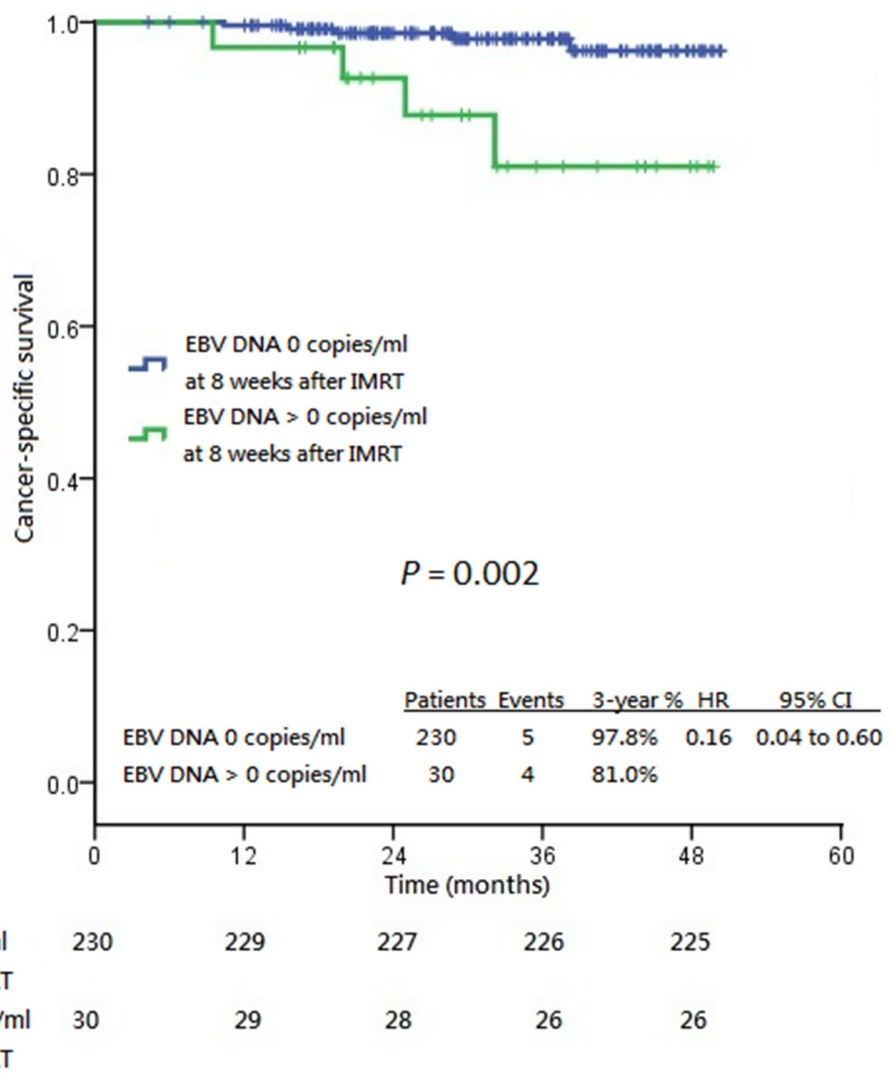

Number at risk

EBV DNA 0 copies/ml at 8 weeks after IMRT EBV DNA > 0 copies $/ \mathrm{m}$ at 8 weeks after IMRT
F

\section{Number at risk} EBV DNA 0 copies/ml at 8 weeks after IMRT EBV DNA > 0 copies/ml at 8 weeks after IMRT

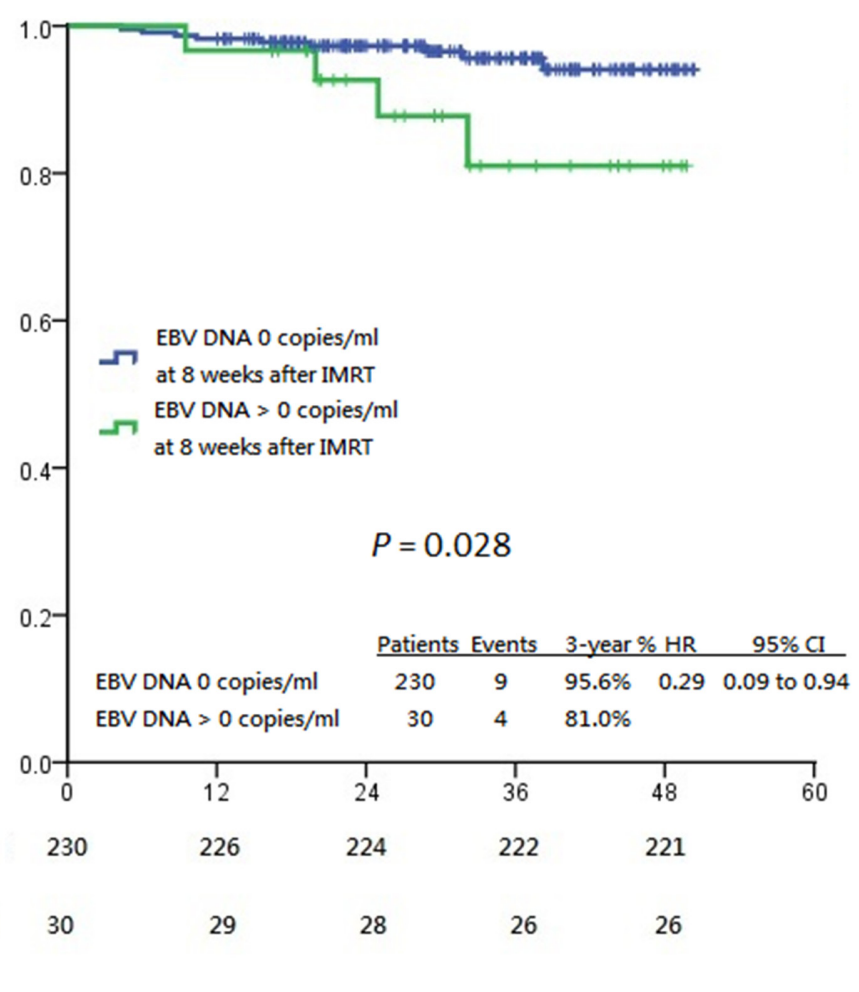

Figure 3 (Continued): Panel E. shows cancer-specific survival and Panel F. shows overall survival, all stratified by post-IMRT 8th week plasma EBV DNA 0 copies/ml and post-IMRT 8th week plasma EBV DNA >0 copies/ml. CI: confidence interval, HR: hazard ratio, IMRT: intensity-modulated radiation therapy. 
A

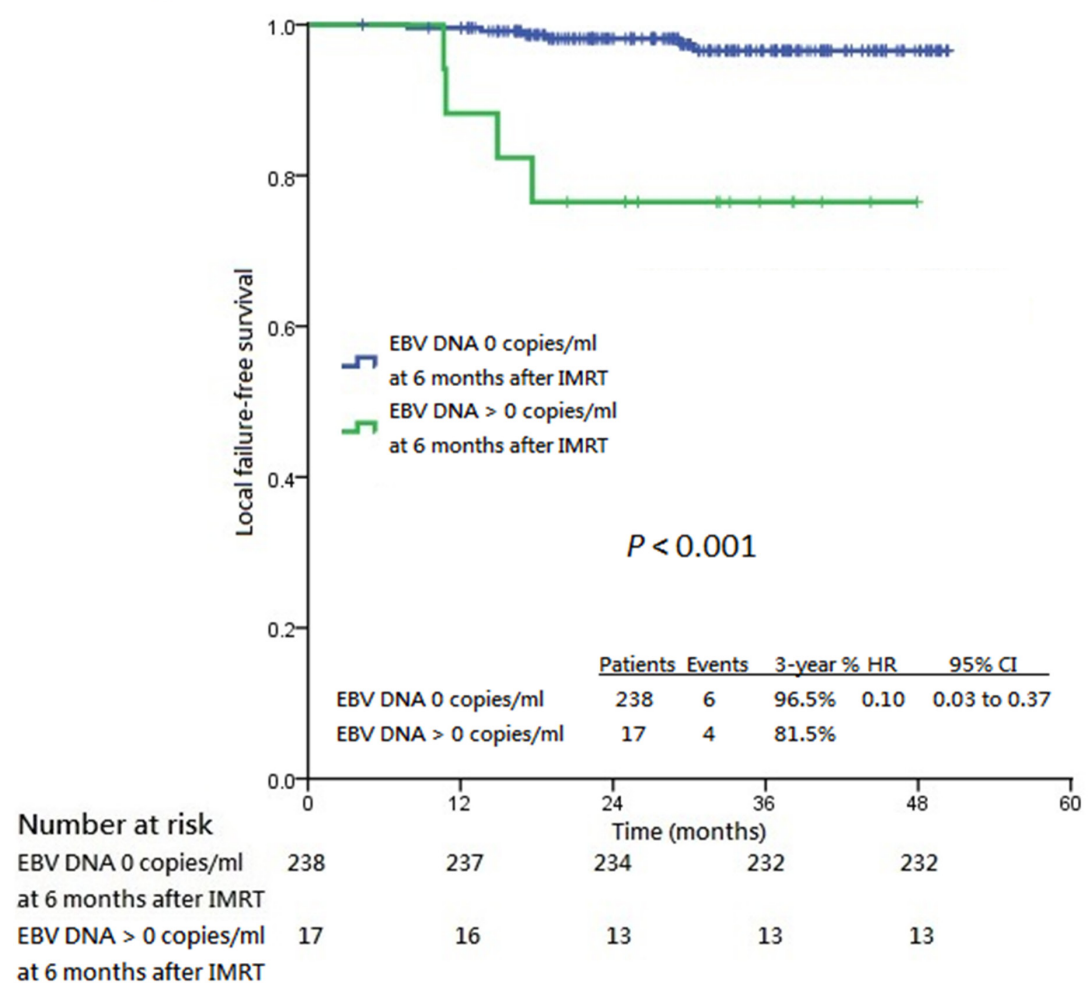

B

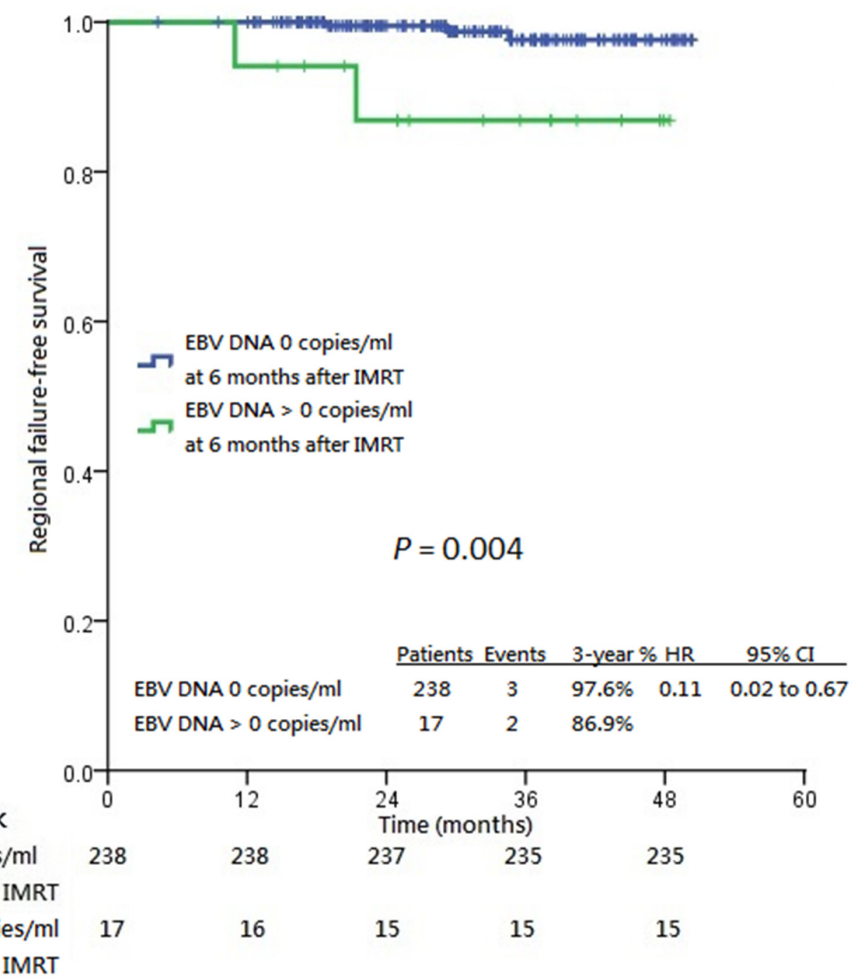

Figure 4: Kaplan-Meier estimates of all survival endpoints stratified by post-IMRT 6th month undetectable plasma EBV DNA. Panel A. shows local failure-free survival. Panel B. shows regional failure-free survival. 
C

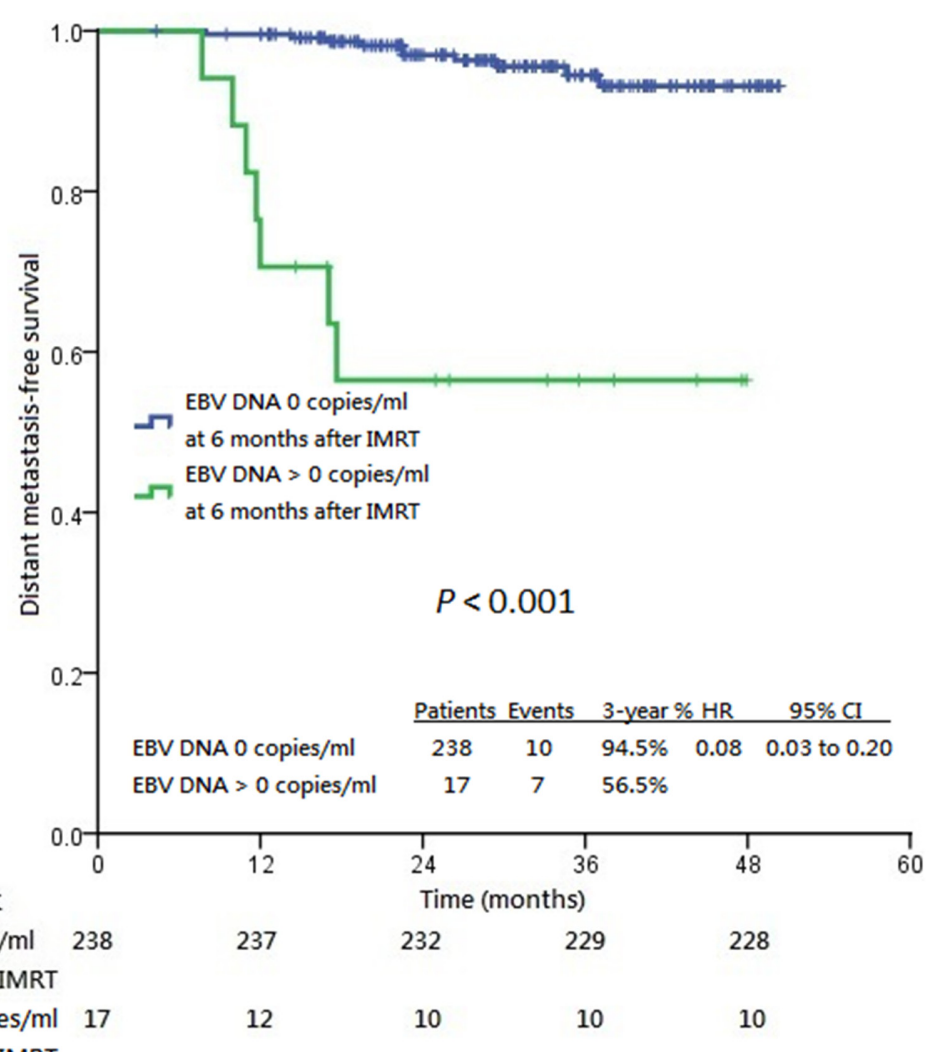

Number at risk

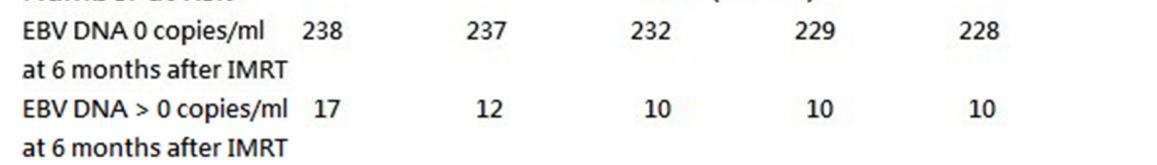

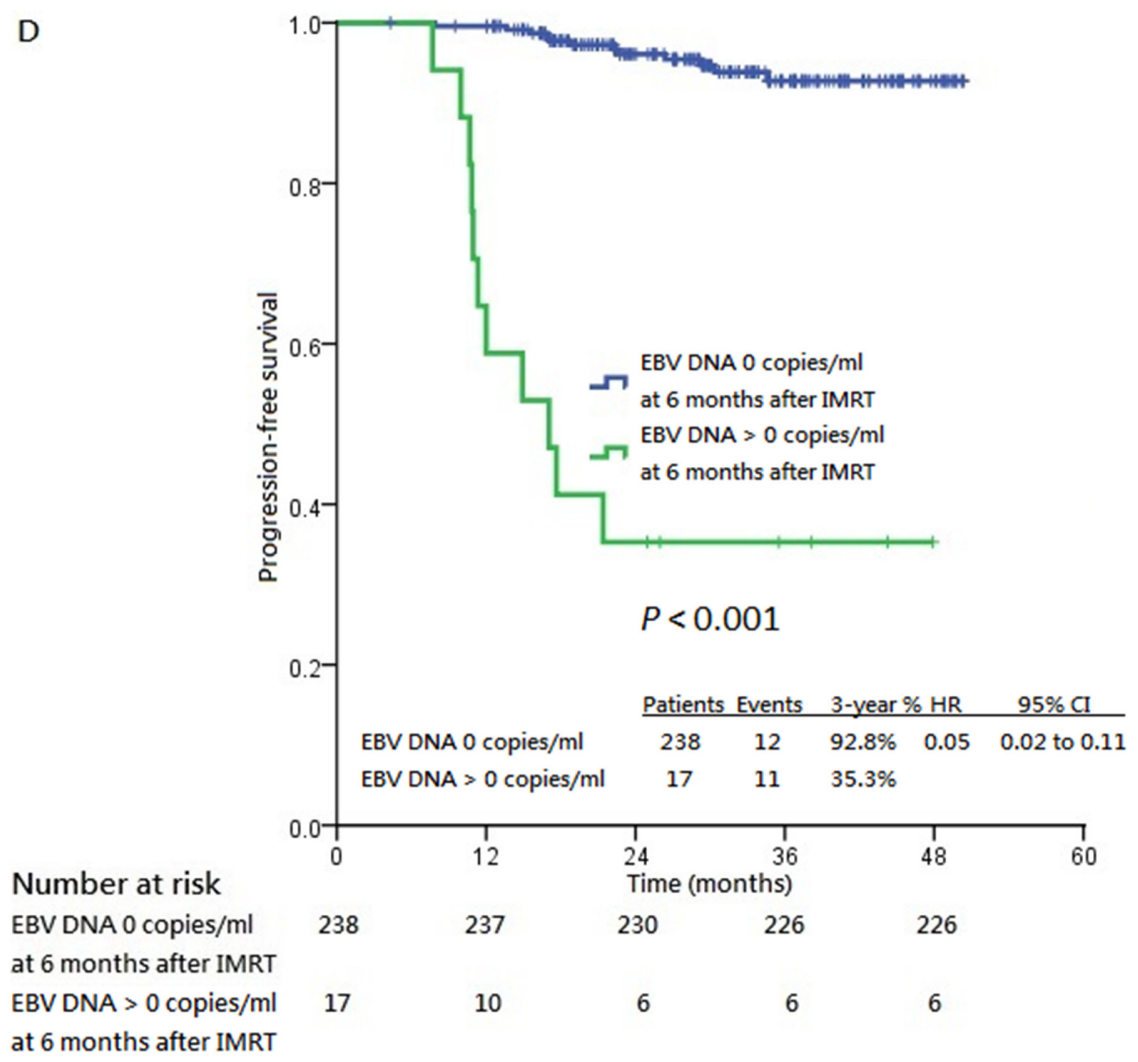

Figure 4 (Continued): Panel C. shows distant metastasis-free survival. Panel D. shows progression-free survival. 


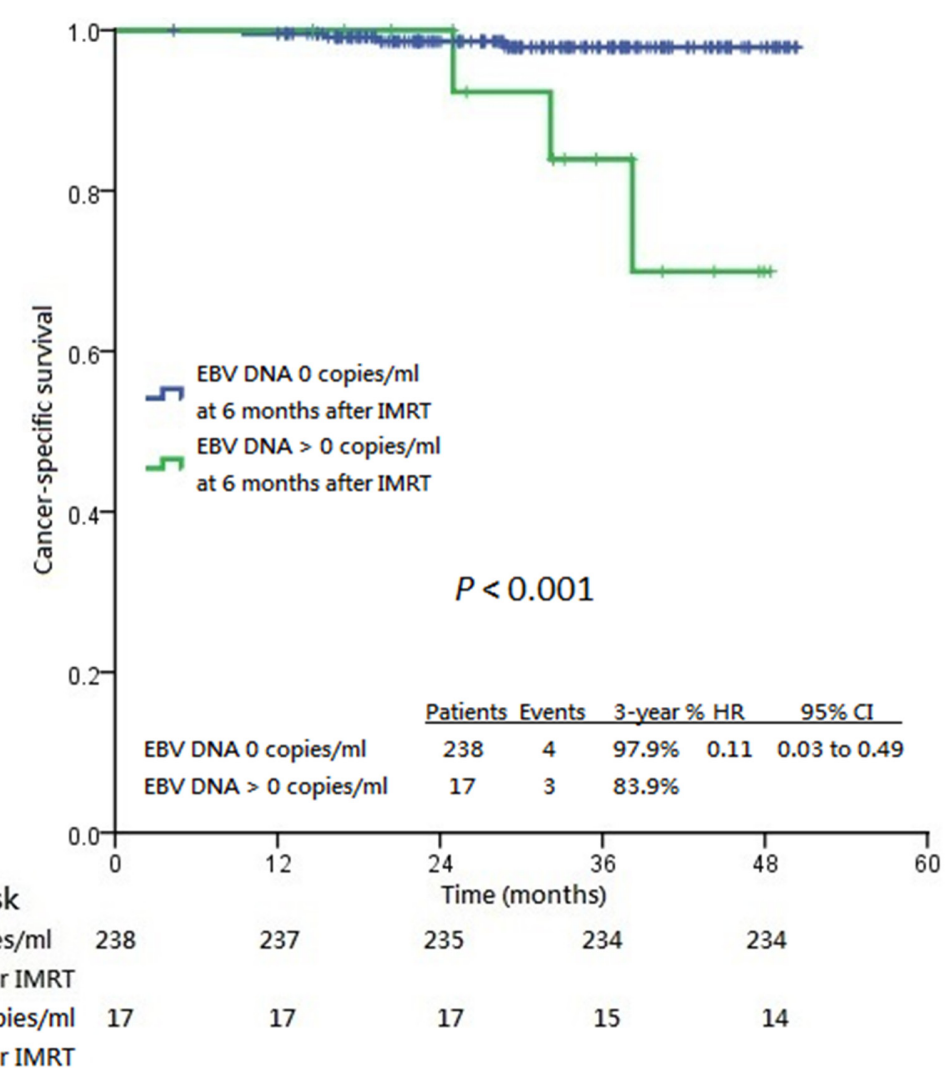

$\begin{array}{lccccc}\begin{array}{l}\text { Number at risk } \\ \text { EBV DNA } 0 \text { copies/ml }\end{array} & 238 & 237 & 235 & 234 & 234 \\ \begin{array}{l}\text { at } 6 \text { months after IMRT } \\ \text { EBV DNA }>0 \text { copies/ml }\end{array} & 17 & 17 & 17 & 15 & 14 \\ \text { at } 6 \text { months after IMRT } & & & & & \end{array}$

F

Number at risk EBV DNA 0 copies/ml at 6 months after IMRT EBV DNA > 0 copies/ml 17 at 6 months after IMRT

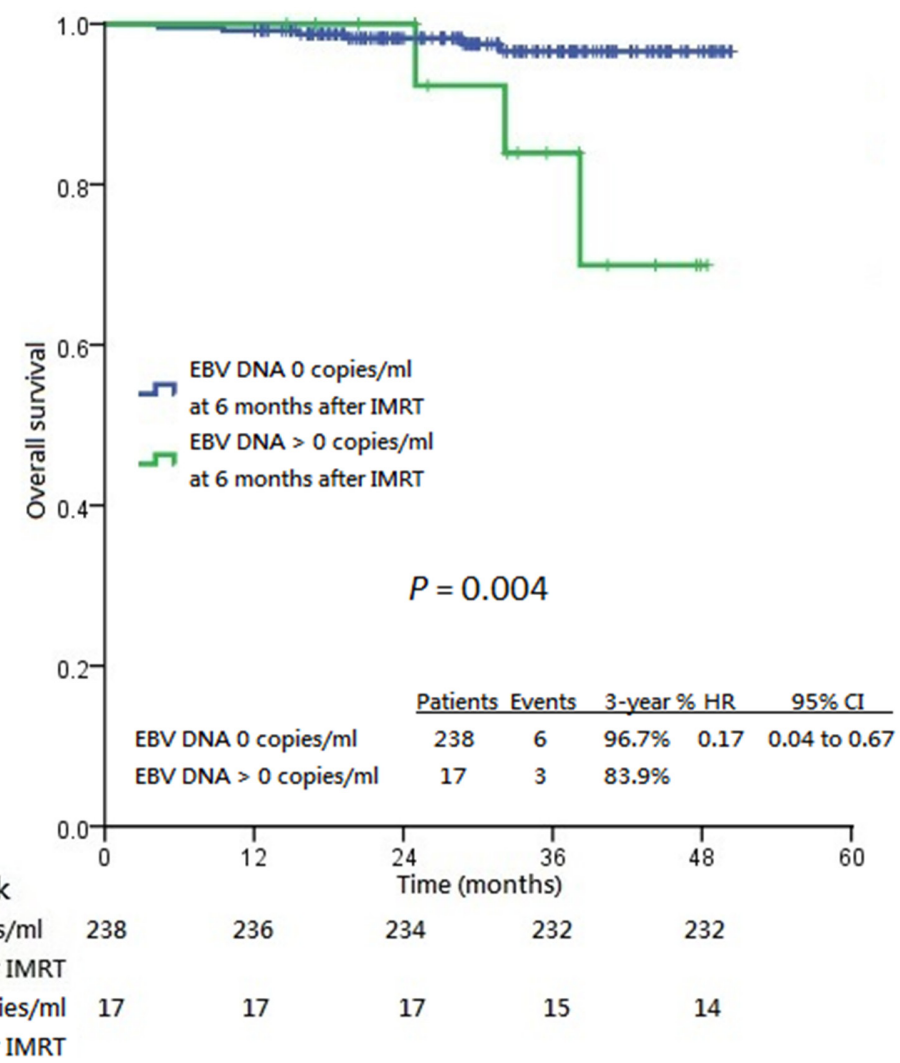

Figure 4 (Continued): Panel E. shows cancer-specific survival and Panel F. shows overall survival, all stratified by post-IMRT 6th month plasma EBV DNA 0 copies $/ \mathrm{ml}$ and post-IMRT 6th month plasma EBV DNA $>0$ copies $/ \mathrm{ml}$. CI: confidence interval, HR: hazard ratio, IMRT: intensity-modulated radiation therapy. 
retrospective study showed the prognostic value of postIMRT plasma EBV DNA on survival outcomes, blood taking for plasma EBV DNA was checked at only one time point after IMRT and the exact date of measurement was not specified [24]. On the contrary, our study is the first prospective observational studies investigating the prognosticative role of baseline and serial post-IMRT plasma EBV DNA titers on various predefined survival endpoints on the basis of complete PET-CT staging and full IMRT implementation.

In addition, the method of measuring plasma EBV DNA was in line with that mentioned in the previous study be Le et al which correlated the plasma EBV DNA titers of 40 samples in each of the four tertiary referral centers in the United States, Taiwan and Hong Kong [25]. The EBV DNA copy numbers were all determined by real-time quantitative polymerase chain reaction (qPCR) (BamHI-Wprimer/ probe). A large variabiltiy of plasma EBV DNA titers was observed, especially when different PCR master mixes and calibrators were used. After study harmonization and standardization with the use of same master mixes and calibrators, correlations were more than $99 \%$ between the centers. A uniform and consistent method of EBV DNA assay should be employed in future multi-center prospective studies.

Our excellent treatment results were likely attributed to complete radiological staging, dedicated IMRT contouring and planning, and close posttreatment surveillance. The median survival was thus not reached in all subgroups due to a lack of failure events. This also explained why the other prespecified baseline covariates including stage and baseline plasma EBV DNA were not good segregators of survival difference. Our preliminary 3-year survival endpoints are also representative indicators of long-term survival outcomes, as only $0(0 \%), 0(0 \%)$ and one $(0.4 \%)$ patient developed local, regional and distant failure respectively at more than three years after IMRT. This echoed the large retrospective study in China which included 868 patients with non-metastatic NPC treated with IMRT with or without adjunct chemotherapy, with the vast majority of treatment failures occurring within the $1^{\text {st }}$ to $3^{\text {rd }}$ year after treatment [26]. This highlighted the crucial importance of frequent surveillance within the first three years after IMRT. Of course longer follow up with more mature results is needed in our study for the detection of late relapses.

Ordinary ROC, as a tool to evaluate the accuracy of biomarkers with a contemporaneous reference standard, is not robust to predict future events especially survival outcomes at a future time point. Instead, TDROC employs another reference standard which refers to an event at a future time and may not be known for every patient due to early censoring [27]. This is particularly favorable to predict survival of a highly curable cancer with few failure and survival events [28]. We found that, from TDROC analysis, higher $\mathrm{Ct}$ indices and AUC values were observed in stage IVA to IVB diseases compared to stage I to III counterparts for all survival endpoints using both postIMRT $8^{\text {th }}$ week and $6^{\text {th }}$ month undetectable plasma EBV DNA as stratification. In addition, the $\mathrm{Ct}$ indices and AUC values were consistently higher for post-IMRT $6^{\text {th }}$ month undetectable plasma EBV DNA compared to post-IMRT $8^{\text {th }}$ week undetectable plasma EBV DNA. It could be inferred that post-IMRT undetectable plasma EBV DNA possessed a higher predictive power of survival endpoints for more advanced stage disease than earlier stage disease and the power was stronger with post-IMRT $6^{\text {th }}$ month than with post-IMRT $8^{\text {th }}$ week undetectable titers. We speculated that those with more advanced stage disease had higher baseline plasma EBV DNA titers and so postIMRT undetectable EBV DNA titers should better reflect a higher chance of complete disease remission. Besides, $5(1.9 \%)$ patients developed progressive disease between $8^{\text {th }}$ week and $6^{\text {th }}$ month after IMRT and thus only 255 patients were included in the subsequent time-dependent ROC (TDROC) and survival analysis at 6 months after IMRT. This might be one possible reason why post-IMRT $6^{\text {th }}$ month undetectable plasma EBV DNA was more predictive of survival endpoints compared to post-IMRT $8^{\text {th }}$ week undetectable plasma EBV DNA titers.

Our study demonstrated that most treatment failures were distant metastases following superior locoregional control by IMRT. It may be inferred from our study that it is probably not late for patients to consider additional intensified treatment at 8 weeks after IMRT if their plasma EBV DNA is still detectable, provided that undetectable plasma EBV DNA could be achieved at 6 months after IMRT. This begs the question as to whether additional or more intensified chemotherapy for patients with persistently elevated post-IMRT plasma EBV DNA titers can reduce distant relapse and improve survival. Twu et al demonstrated that adjuvant oral tegafur-uracil for one year with or without preceding intravenous chemotherapy improved distant relapse and OS in patients with persistently detectable plasma EBV DNA taken one week after completion of radiation therapy [29]. This has so far been the only published study indicating a survival benefit of adjuvant chemotherapy in those with persistently elevated plasma EBV DNA after completion of RT. Recently in the largest multi-institutional prospective study in Hong Kong, Hui et al demonstrated that posttreatment, instead of pretreatment, plasma EBV DNA titers were prognostic of relapse-free survival and OS [30]. However, the optimal timing of checking posttreatment plasma EBV DNA has yet to be defined since it may take longer time for complete clearance of plasma EBV DNA after radiation therapy as reported in a previous study [31]. Our current study showed that 30 patients $(11.5 \%)$ still had persistently elevated plasma EBV DNA at eight weeks after IMRT, but 20 patients had complete plasma EBV DNA clearance at later time points without evidence of relapse. Moreover, IMRT was not fully implemented 
in the two aforementioned studies. Whether additional or more intensified adjuvant chemotherapy brings survival benefit may be deciphered by the ongoing Hong Kong NPC-0502 study (NCT00370890), which is designed to assess the benefit of adjuvant chemotherapy in patients at high risk of disease recurrence, identified with detectable plasma EBV DNA at 6 weeks after chemoradiation [32]. The combined phase II and III NRG-HN001 trial (ClinicalTrials.gov NCT02135042) investigating the role of different adjuvant chemotherapy regimens (standard cisplatin and 5-FU regimen versus gemcitabine and paclitaxel combination) as a phase II setting and omission of adjuvant chemotherapy in those with undetectable plasma EBV DNA following IMRT may certainly offer a clearer answer to this unresolved question [33]. However, this will pose another clinical question on the equipoise between survival prolongation and chemotherapy-related toxicities by the administration of additional adjuvant chemotherapy. Chen et al in their phase III multicenter randomized-controlled trial concluded that adjuvant chemotherapy following concurrent chemoradiation failed to improve survival as compared concurrent chemoradiation alone [34]. Of note, $82 \%$ in the concurrent chemoradiation plus adjuvant chemotherapy group started adjuvant chemotherapy and only 63\% completed all cycles of adjuvant chemotherapy. Patient refusal was the principal reason for uncompleted adjuvant chemotherapy. In addition, $69 \%$ and $49 \%$ of patients who received adjuvant chemotherapy had treatment delays and dose reduction respectively, because of adverse events and other reasons. The infrequent use of IMRT in less than half of the study population was another study limitation. Despite lack of improvement in all prespecified survival endpoints, numerically the results favored adjuvant chemotherapy with a $2 \%$ absolute difference in failure-free survival $(P$ $=0.13)$, distant failure-free survival $(P=0.12)$ and OS. Since this study was not designed as a non-inferiority trial against concurrent chemoradiation alone, we cannot strictly conclude that adjuvant chemotherapy brings no benefits in locally advanced NPC. Induction chemotherapy before concurrent chemoradiation, on the other hand, may improve treatment compliance and possibly better systemic control. However, conflicting results were reported in different prospective studies $[35,36]$. More recently, Lee et al in the preliminary analysis of their NPC-0501 study revealed that induction chemotherapy with cisplatin and capecitabine (PX) reflected a significant reduction in the hazards of disease progression and possibly death compared to induction chemotherapy with cisplatin and 5-FU (PF) and adjuvant PF regimen [37]. As a whole, our results suggested that it is inadequate to apply only the TNM staging system for participant selection in clinical trials, and that use of biomarkers will probably enhance the power of future clinical trials to obtain positive results. Our study provided a new insight into the change in the current international practice guidelines of non-metastatic NPC treated with IMRT. Personalized treatment intensification should be considered for those who show early serological signs of relapse, which should be confirmed in prospective randomized-controlled trials.

In conclusion, early serial undetectable plasma EBV DNA titers after radical IMRT with or without adjunct chemotherapy were prognostic of better 3-year survival outcomes in patients with non-metastatic nasopharyngeal carcinoma.

\section{MATERIALS AND METHODS}

\section{Study design and population}

Patients with newly diagnosed non-metastatic NPC of undifferentiated type (WHO Type III) treated with IMRT as a curative treatment were recruited into this prospective observational study since July 2010 with prior approval by the local institutional review board of our institution. The study was undertaken in accordance with Declaration of Helsinki and Good Clinical Practice guidelines. After written informed consent, all patients had pretreatment workup including serum hematology and biochemistry, plasma EBV DNA, $[18 \mathrm{~F}]$ fluorodeoxyglucose $\left({ }^{18} \mathrm{~F}-\mathrm{FDG}\right)$ positron-emission tomography with integrated contrast-enhanced computed tomography (PET-CT) scan with patients immobilized by a prefabricated customized head and neck thermoplastic cast, and magnetic resonance imaging (MRI) including T1, T2 and fat-suppressed contrast-enhanced T1 sequences of the head and neck in treatment position by 3T scanner (Arhieva 3.0 T, Philips Healthcare, Best, The Netherlands) on the following day as previously described to exclude those with distant metastasis or second primary malignancy and for IMRT target delineation and planning (Supplementary Data). Two independent radiologists specialized in head and neck radiology and blinded to treatment details determined the stage and tumor extent; any discrepancies were resolved by consensus, based on the $7^{\text {th }}$ edition of AJCC classification. Plasma EBV DNA was extracted and calculated as previously described (Supplementary Data) [12]. All patients also underwent endoscopy and nasopharyngeal biopsies on both sides of the nasopharynx to assess extent of mucosal tumor spread. Then they received IMRT as described (Supplementary Data) [38]. Briefly, 70 Gy was delivered to the planning target volume (PTV)-70 and 66 Gy to the PTV-66 in 33 fractions by the simultaneous accelerated radiation therapy technique. In general, patients with stage I and II disease received IMRT alone while stage III to IVB patients received concurrent chemoradiation with the Intergroup 0099 regimen consisting of cisplatin intravenous infusion $\left(100 \mathrm{mg} / \mathrm{m}^{2}\right)$ every three weeks starting on the $1^{\text {st }}$ day of IMRT and adjuvant chemotherapy with cisplatin on day 1 and 5-FU from day 1 to 4 for three more cycles starting at four weeks following IMRT [39]. Patients with 
bulky cervical nodal ( $\geq 3 \mathrm{~cm}$ in diameter) stage II disease were also given concurrent chemoradiation only, at the discretion of the treating oncologist. Patients who had their primary tumors in close proximity to normal critical organs-at-risk (OARs) would receive 3 cycles of induction chemotherapy (cisplatin $100 \mathrm{mg} / \mathrm{m}^{2}$ on day 1 and $5-\mathrm{FU}$ $1000 \mathrm{mg} / \mathrm{m}^{2}$ from day 1 to 5 every three weeks) before concurrent chemoradiation, in an attempt for significant tumor shrinkage so that a radical radiation dose could be delivered to the tumors with more sparing of these OARs. At 8 weeks following completion of IMRT, all patients had routine 6-site random nasopharyngeal biopsies as our standard practice and blood checked for plasma EBV DNA titers (Figure 1) [40]. Local salvage treatment was given to patients who had persistent primary tumor at 12 weeks after IMRT [41]. If their plasma EBV DNA was still $>0$ copies/ml at 8 weeks after IMRT, it would be repeated 4 weeks thereafter until it was undetectable or it was proven to have persistent locoregional disease or metastasis clinically or radiologically. Patients with complete local remission had follow up clinical evaluation every 2 to 3 months, surveillance MRI scan every 3 to 4 months, and PET-CT scan if clinically suspicious of relapse. Plasma EBV DNA was measured again at 6 months after IMRT and then as clinically indicated afterwards. Any elevation of plasma EBV DNA would lead to endoscopy and nasopharyngeal biopsy, MRI and PET-CT evaluation and subsequent salvage treatment if recurrence was confirmed.

\section{Statistical analysis}

The prespecified survival endpoints including local failure-free survival (LFFS), regional failurefree survival (RFFS), distant metastasis-free survival (DMFS), progression-free survival (PFS), cancerspecific survival (CSS) and overall survival (OS) were defined and evaluated by log rank tests (Supplementary Data). Univariable and multivariable analyses by Cox proportional hazard models were employed for identifying prognostic factors for these survival endpoints with age, sex, Eastern Cooperative Oncology Group (ECOG) performance status (PS), T-classification, $\mathrm{N}$-classification, overall stage of NPC, IMRT alone versus chemoradiation, concurrent chemoradiation only, induction chemotherapy then concurrent chemoradiation, concurrent chemoradiation then adjuvant chemotherapy and baseline and post-IMRT $8^{\text {th }}$ week and $6^{\text {th }}$ month undetectable plasma EBV DNA titers as covariates. Timedependent receiver-operating characteristics (TDROC) analyses were performed to obtain time-dependent concordance indices $(\mathrm{Ct})$ and area under the curve (AUC) for advanced stage IVA to IVB disease versus stage I to III disease [42]. Nonparametric bootstrapping with 1000 replicates was also used to determine 95\% confidence interval $(\mathrm{CI})$ of the $\mathrm{Ct}$ and to evaluate the difference in $\mathrm{Ct}$ indices between these disease groups. TDROC was performed by the statistical software package $\mathrm{R}$ version 3.1.3 [43]. The other statistical analyses were performed by Statistical Package for Social Sciences (SPSS) version 20. Tests were considered statistically significant at $P<$ 0.05 (two-sided). The database-lock date for analysis was December 30, 2015.

This study was presented in part as an oral abstract at $51^{\text {st }}$ American Society of Clinical Oncology (ASCO) Annual Meeting (Abstract 6007), Chicago, IL, May 29June 2, 2015. Clinical trial information: NCT02476669 (ClincalTrials.gov).

\section{CONFLICTS OF INTEREST}

The authors declare no conflicts of interest.

\section{GRANT SUPPORT}

This study was supported by SK Yee Medical Foundation (project number 210212, 211259 and 213208). The costs of publication of this article were defrayed by the authors and not by the funder.

\section{REFERENCES}

1. Jia WH, Huang QH, Liao J, Ye W, Shugart YY, Liu Q, Chen LZ, Li YH, Lin X, Wen FL, Adami HO, Zeng Y, et al. Trends in incidence and mortality of nasopharyngeal carcinoma over a 20-25 year period (1978/1983-2002) in Sihui and Cangwu counties in southern China. BMC Cancer. 2006; 6:178-86.

2. Parkin DM, Bray F, Ferlay J, Pisani P. Global cancer statistics, 2002. CA Cancer J Clin. 2005; 55:74-108.

3. Baujat B, Audry H, Bourhis J, Chan AT, Onat H, Chua DT, Kwong DL, Al-Sarraf M, Chi KH, Hareyama M, Leung SF, Thephamongkhol K, et al. Chemotherapy in locally advanced nasopharyngeal carcinoma: an individual patient data meta-analysis of eight randomized trials and 1753 patients. Int J Radiat Oncol Biol Phys. 2006; 64:47-56.

4. Lee N, Xia P, Quivey JM, Sultanem K, Poon I, Akazawa C, Akazawa P, Weinberg V, Fu KK. Intensity-modulated radiotherapy in the treatment of nasopharyngeal carcinoma: an update of the UCSF experience. Int J Radiat Oncol Biol Phys. 2002; 53:12-22.

5. Kam MK, Teo PM, Chau RM, Cheung KY, Choi PH, Kwan WH, Leung SF, Zee B, Chan AT. Treatment of nasopharyngeal carcinoma with intensity-modulated radiotherapy: The Hong Kong experience. Int J Radiat Oncol Biol Phys. 2004; 60:1440-50.

6. Wolden SL, Chen WC, Pfister DG, Kraus DH, Berry SL, Zelefsky MJ. Intensity-modulated radiation therapy (IMRT) for nasopharynx cancer: update of the Memorial SloanKettering experience. Int J Radiat Oncol Biol Phys. 2006; 64:57-62. 
7. Kam MK, Leung SF, Zee B, Chau RM, Suen JJ, Mo F, Lai M, Ho R, Cheung KY, Yu BK, Chiu SK, Choi PH, et al. Prospective randomized study of intensity-modulated radiotherapy on salivary gland function in early-stage nasopharyngeal carcinoma patients. J Clin Oncol. 2007; 25:4873-9.

8. Lee N, Harris J, Garden AS, Straube W, Glisson B, Xia P, Bosch W, Morrison WH, Quivey J, Thorstad W, Jones C, Ang KK. Intensity-modulated radiation therapy with or without chemotherapy for nasopharyngeal carcinoma: radiation therapy oncology group phase II trial 0225 . J Clin Oncol. 2009; 27:3684-90.

9. Wong FC, Ng AW, Lee VH, Lui CM, Yuen KK, Sze WK, Leung TW, Tung SY. Whole-field simultaneous integrated boost intensity modulated radiotherapy for patients with nasopharyngeal carcinoma. Int J Radiat Oncol Biol Phys. 2010; 76:138-45.

10. Ng WT, Lee MC, Hung WM, Choi CW, Lee KC, Chan OS, Lee AW. Clinical outcomes and patterns of failure after intensity-modulated radiotherapy for nasopharyngeal carcinoma. Int J Radiat Oncol Biol Phys. 2011; 79:420-8.

11. Lee NY, Zhang Q, Pfister DG, Kim J, Garden AS, Mechalakos J, Hu K, Le QT, Colevas AD, Glisson BS, Chan AT, Ang KK. Addition of bevacizumab to standard chemoradiation for locoregionally advanced nasopharyngeal carcinoma (RTOG 0615): a phase 2 multi-institutional trial. Lancet Oncol. 2012; 13:172-80.

12. Lo YM, Chan LY, Lo KW, Leung SF, Zhang J, Chan AT, Lee JC, Hjelm NM, Johnson PJ, Huang DP. Quantitative analysis of cell-free Epstein-Barr virus DNA in plasma of patients with nasopharyngeal carcinoma. Cancer Res. 1999; 59:1188-91.

13. Lo YM, Chan AT, Chan LY, Leung SF, Lam CW, Huang DP, Johnson PJ. Molecular prognostication of nasopharyngeal carcinoma by quantitative analysis of circulating EpsteinBarr virus DNA. Cancer Res. 2000; 60:6878-81.

14. Lo YM, Leung SF, Chan LY, Lo KW, Zhang J, Chan AT, Lee JC, Hjelm NM, Johnson PJ, Huang DP. Plasma cellfree Epstein-Barr virus DNA quantitation in patients with nasopharyngeal carcinoma. Correlation with clinical staging. Ann NY Acad Sci. 2000; 906:99-101.

15. Lin JC, Wang WY, Chen KY, Wei YH, Liang WM, Jan JS, Jiang RS. Quantification of plasma Epstein-Barr virus DNA in patients with advanced nasopharyngeal carcinoma. N Engl J Med. 2004; 350:2461-70.

16. Lin JC, Wang WY, Liang WM, Chou HY, Jan JS, Jiang RS, Wang JY, Twu CW, Liang KL, Chao J, Shen WC. Longterm prognostic effects of plasma Epstein-Barr virus DNA by minor groove binder-probe real-time quantitative PCR on nasopharyngeal carcinoma patients receiving concurrent chemoradiotherapy. Int J Radiat Oncol Biol Phys. 2007; 68:1342-8.

17. Hou X, Zhao C, Guo Y, Han F, Lu LX, Wu SX, Li S, Huang PY, Huang H, Zhang L. Different clinical significance of pre- and post-treatment plasma Epstein-Barr virus DNA load in nasopharyngeal carcinoma treated with radiotherapy. Clin Oncol (R Coll Radiol). 2011; 23:128-33.

18. Le QT, Jones CD, Yau TK, Shirazi HA, Wong PH, Thomas EN, Patterson BK, Lee AW, Zehnder JL. A comparison study of different PCR assays in measuring circulating plasma Epstein Barr virus DNA levels in patients with nasopharyngeal carcinoma. Clin Cancer Res. 2005; 11:5700-7.

19. Wang WY, Twu CW, Chen HH, Jiang RS, Wu CT, Liang KL, Shih YT, Chen CC, Lin PJ, Liu YC, Lin JC. Long-term survival analysis of nasopharyngeal carcinoma by plasma Epstein Barr virus DNA levels. Cancer. 2013; 119:963-70.

20. Leung SF, Zee B, Ma BB, Hui EP, Mo F, Lai M, Chan KC, Chan LY, Kwan WH, Lo YM, Chan AT. Plasma EpsteinBarr viral deoxyribonucleic acid quantitation complements tumor-node-metastasis staging prognostication in nasopharyngeal carcinoma. J Clin Oncol. 2006; 24:5414-8.

21. Chan AT, Lo YM, Zee B, Chan LY, Ma BB, Leung SF, Mo F, Lai M, Ho S, Huang DP, Johnson PJ. Plasma EpsteinBarr virus DNA and residual disease after radiotherapy for undifferentiated nasopharyngeal carcinoma. J Natl Cancer Inst. 2002; 94:1614-9.

22. Leung SF, Chan KC, Ma BB, Hui EP, Mo F, Chow KC, Leung L, Chu KW, Zee B, Lo YM, Chan AT. Plasma Epstein-Barr viral DNA load at midpoint of radiotherapy course predicts outcome in advanced-stage nasopharyngeal carcinoma. Ann Oncol. 2014; 25:1204-8.

23. Chan AT, Grégoire V, Lefebvre JL, Licitra L, Hui EP, Leung SF, Felip E; EHNS-ESMO-ESTRO Guidelines Working Group. Nasopharyngeal cancer: EHNS-ESMO-ESTRO Clinical Practice Guidelines for diagnosis, treatment and follow-up. Ann Oncol. 2012; 23:vii83-5.

24. Peng H, Guo R, Chen L, Zhang Y, Li WF, Mao YP, Sun Y, Zhang F, Liu LZ, Lin AH, Ma J. Prognostic impact of plasma Epstein-Barr virus DNA in patients with nasopharyngeal carcinoma treated using intensitymodulated radiation therapy. Sci Rep. 2016; 6:22000.

25. Le QT, Zhang Q, Cao H, Cheng AJ, Pinsky BA, Hong RL, Chang JT, Wang CW, Tsao KC, Lo YD, Lee N, Ang KK, Chan AT, Chan KC. An international collaboration to harmonize the quantitative plasma Epstein-Barr virus DNA assay for future biomarker-guided trials in nasopharyngeal carcinoma. Clin Cancer Res. 2013; 19:2208-2215.

26. Sun X, Su S, Chen C, Han F, Zhao C, Xiao W, Deng $\mathrm{X}$, Huang S, Lin C, Lu T. Long-term outcomes of intensity-modulated radiotherapy for 868 patients with nasopharyngeal carcinoma: an analysis of survival and treatment toxicities. Radiother Oncol. 2014; 110:398-403.

27. Heagerty PJ, Lumley T, Pepe MS. Time-dependent ROC curves for censored survival data and a diagnostic marker. Biometrics. 2000; 56:337-44.

28. Foucher Y, Danger R. Time dependent ROC curves for the estimation of true prognostic capacity or microarray data. Stat Appl Genet Mol Biol. 2012; 11:Article 1. 
29. Twu CW, Wang WY, Chen CC, Liang KL, Jiang RS, Wu CT, Shih YT, Lin PJ, Liu YC, Lin JC. Metronomic adjuvant chemotherapy improves treatment outcome in nasopharyngeal carcinoma patients with postradiation persistently detectable plasma Epstein-Barr virus deoxyribonucleic acid. Int J Radiat Oncol Biol Phys. 2014; 89:21-9.

30. Hui EP, Ma BB, Chan KC, Chan CM, Wong CS, To KF, Chan AW, Tung SY, Ng WT, Cheng AC, Lee VH, Chan SL, et al. Clinical utility of plasma Epstein-Barr virus DNA and ERCC1 single nucleotide polymorphism in nasopharyngeal carcinoma. Cancer. 2015; 121:2720-9.

31. To EW, Chan KC, Leung SF, Chan LY, To KF, Chan AT, Johnson PJ, Lo YM. Rapid clearance of plasma EpsteinBarr virus DNA after surgical treatment of nasopharyngeal carcinoma. Clin Cancer Res. 2003; 9:3254-9.

32. Chan ATC, Ngan RKC, Hui EP, Leung SF, Poon P, Sin VC, Tung SY, Cheng ASK, Yau TK, Lee V, Ma B, Cheng HC, et al. A multicenter randomized controlled trial of adjuvant chemotherapy in nasopharyngeal carcinoma with residual plasma EBV DNA following primary radiotherapy or chemoradiotherapy. J Clin Oncol. 2012; 30:15s. (Suppl; abstr 5511)

33. NRG-HN001 Protocol Information Randomized phase II and Phase III studies of individualized treatment for nasopharyngeal carcinoma based on biomarker Epstein Barr virus (EBV) deoxyribonucleic acid (DNA). http:// www.rtog.org/ClinicalTrials/ProtocolTable/studyDetails. aspx?study=1305. Accessed August 20, 2015.

34. Chen L, Hu CS, Chen XZ, Hu GQ, Cheng ZB, Sun Y, Li WX, Chen YY, Xie FY, Liang SB, Chen Y, Xu TT, et al. Concurrent chemoradiotherapy plus adjuvant chemotherapy versus concurrent chemoradiotherapy alone in patients with locoregionally advanced nasopharyngeal carcinoma: a phase 3 multicentre randomised controlled trial. Lancet Oncol. 2012; 13:163-71.

35. Hui EP, Ma BB, Leung SF, King AD, Mo F, Kam MK, Yu BK, Chiu SK, Kwan WH, Ho R, Chan I, Ahuja AT, et al. Randomized phase II trial of concurrent cisplatinradiotherapy with or without docetaxel and cisplatin in advanced nasopharyngeal carcinoma. J Clin Oncol. 2009; 27:242-9.
36. Fountzilas G, Ciuleanu E, Bobos M, Kalogera-Fountzila A, Eleftheraki AG, Karayannopoulou G, Zaramboukas T, Nikolaou A, Markou K, Resiga L, Dionysopoulos D, Samantas E, et al. Induction chemotherapy followed by concomitant radiotherapy and weekly cisplatin versus the same concomitant chemoradiotherapy in patients with nasopharyngeal carcinoma: a randomized phase II study conducted by the Hellenic Cooperative Oncology Group (HeCOG) with biomarker evaluation. Ann Oncol. 2012; 23:427-35.

37. Lee AW, Ngan RK, Tung SY, Cheng A, Kwong DL, Lu TX, Chan AT, Chan LL, Yiu H, Ng WT, Wong F, Yuen KT, et al. Preliminary results of trial NPC-0501 evaluating the therapeutic gain by changing from concurrent-adjuvant to induction-concurrent chemoradiotherapy, changing from fluorouracil to capecitabine, and changing from conventional to accelerated radiotherapy fractionation in patients with locoregionally advanced nasopharyngeal carcinoma. Cancer. 2015; 121:1328-38.

38. Lee VHF, Ng SCY, Leung TW, Au GK, Kwong DL. Dosimetric predictors for radiation-induced acute nausea and vomiting in IMRT for nasopharyngeal carcinoma. Int J Radiat Oncol Biol Phys. 2012; 84:176-82.

39. Al-Sarraf M, LeBlanc M, Giri PG, Fu KK, Cooper J, Vuong T, Forastiere AA, Adams G, Sakr WA, Schuller DE, Ensley JF. Chemoradiotherapy versus radiotherapy in patients with advanced nasopharyngeal cancer: phase III randomized intergroup study 0099. J Clin Oncol. 1998; 16:1310-7.

40. Kwong DL, Nicholls J, Wei WI, Chua DT, Sham JS, Yuen PW, Cheng AC, Yau CC, Kwong PW, Choy DT. Correlation of endoscopic and histologic finding before and after treatment for nasopharyngeal carcinoma. Head Neck. 2001; 23:34-41.

41. Nicholls JM, Sham J, Chan CW, Choy D. Radiation therapy for nasopharyngeal carcinoma: histologic appearance and patterns of tumor regression. Hum Pathol. 1992; 23:742-47.

42. Heagerty PJ, Zheng Y. Survival model predictive accuracy and ROC curves. Biometrics. 2005; 61:92-105.

43. The R Project for Statistical Computing. http://www.Rproject.org. Accessed December 20, 2014. 